\author{
Dana ADAMCOVÁ ${ }^{1}$, František TOMAN ${ }^{1}$, Magdalena VAVERKOVÁ ${ }^{1 *}$ \\ and Jana KOTOVICOVÁ ${ }^{1}$
}

\title{
THE EFFECT OF BIODEGRADATION/DEGRADATION OF DEGRADABLE PLASTIC MATERIAL ON COMPOST QUALITY
}

\author{
WPLYW BIODEGRADACJI/DEGRADACJI MATERIAŁÓW \\ Z TWORZYW SZTUCZNYCH NA JAKOŚĆ KOMPOSTU
}

\begin{abstract}
The objective of this study was to find out whether the quality of compost would change during the process of composting carrier bags claimed by manufacturers as compostable or biodegradable in terms of parameters stipulated in the standard ČSN 465735 Industrial composts. Eight samples were subjected to the composting process in laboratory conditions. The compost samples were analyzed in the accredited laboratory. All samples met parameters stipulated for Class II. Seven samples of the eight met parameters stipulated in the standard ČSN 465735 for Class I. The samples had no influence on compost characteristics: strength, content of water and salt, $\mathrm{pH}$ value, content of nutrients or proportion of organic substances; other components of the compost remained unchanged. Optical changes of the compost did not occur either.
\end{abstract}

Keywords: biodegradability, compostability, degradation, controlled environment

\section{Introduction}

Composting is a managed process that controls the biological decomposition and transformation of biodegradable materials into a humus-like substance called compost. The controlled biooxidation process proceeds through mesophilic and thermophilic phases and results in the production of carbon dioxide, water, minerals and stabilized organic matter (compost or humus). Another benefit of this process is that the heat produced can result in destruction of pathogens that may be present in the waste stream. For most operations, including plastic biodegradation, a combination of sludge and solid waste provides the best operation. The plastic product or material must disintegrate during composting such that the residual plastic is not readily distinguishable from other organic materials in the finished compost. A plastic material or product is considered to have demonstrated satisfactory disintegration if after lab-scale composting, no more than $10 \%$ of its original dry weight

\footnotetext{
${ }^{1}$ Department of Applied and Landscape Ecology, Faculty of Agronomy, Mendel University in Brno, Zemědělská 1, 61300 Brno, Czech Republic, phone +420 545132484

*Corresponding author: magda.vaverkova@uake.cz
} 
remains after sieving on a $2.0 \mathrm{~mm}$ sieve. That is, $90 \%$ of the test sample must pass through a $2.0 \mathrm{~mm}$ sieve $[1,2]$.

Composting of biodegradable packaging and biodegradable plastics is a form of recovery of waste which can cut the increasing need of new landfilling sites. Only compostable materials can be recycled through biological treatment, since materials not compatible with composting could decrease the compost quality and impair its commercial value. The environmental conditions of the composting test are the following: high temperature $\left(58^{\circ} \mathrm{C}\right)$; aerobic conditions; proper water content (about $50 \%$ ). Mature compost is used as a solid matrix, as a source of thermophilic microorganisms (inoculum), and as a source of nutrients. Avery important requisite is that the packaging material under study must not release, during degradation, toxic compounds into the compost which could hinder plants, animals, and human beings by entering the food chain $[1,2]$.

Recently, studies have been carried out on the degradation of biodegradable plastic in the composting process [3-5]. Gu et al [3] ascertained the rate of degradation of cellulose acetate films when exposed to composting materials in laboratory test vessels maintained at $53^{\circ} \mathrm{C}$ by measuring their weight loss. Weiland et al [5] examined the degradability of thermally oxidized polyethylene film in the composting process by monitoring its molecular weight and surface erosion. Choi and Park [6] reported on the biodegradability of polycaprolactone/styrene-acrylonitrile-copolymer blend in the composting process. By measuring the weight loss of the blend film, which contained more than $50 \%$ polycaprolactone by weight, they found that it became significantly degraded during the composting time. Yue et al [7] measured the biodegradation of films composed of poly(b-hydroxybutyrate) and a copolymer of $20 \%$ b-hydroxyvalyrate by observing weight loss and normalized thickness. They reported that $\mathrm{P}(\mathrm{b}-\mathrm{HB}-\mathrm{co}-20 \%$ b-HV) degraded significantly faster in a simulated municipal solid waste compost test at a constant temperature of $55^{\circ} \mathrm{C}$. In addition to these studies, other research has attempted to evaluate the degradability of biodegradable plastic during composting by measuring the weight loss of the plastic film [8-14]. Although much research has been carried out on the degradability of biodegradable plastics in the composting process, few studies have controlled composting process and that the quality of the produced compost has not altered when biodegradable/degradable polymers has been mineralized.

In our previous study [15], we determine the degrability/biodegradability of "single-use" plastic bags available on the market that are labeled as degradable/biodegradable and those certified as compostable. This paper discusses the potential impact of biodegradable/degradable plastics, with particular reference to single use plastics bags, via composting in a laboratory-scale test. The test should prove that the biodegradable plastics could be biodegraded during a controlled composting process and that the quality of the produced compost has not altered, when, biodegradable polymers had been mineralized. Specific examples are given from new research on biodegradability in simulated composting systems.

\section{Experimental procedures}

\section{Samples for composting}

Seven kinds of degradable/biodegradable bags as well as cellulose filter paper (CFP) as a positive control (reference mixture) were qualitatively tested for disintegration in 
a laboratory-scale test. Individual samples are described in the Table 1 [15]. Block diagram of the experiment setup is described in the Figure 1.

Samples placed in each reactor

\begin{tabular}{|c|c|c|}
\hline Sample & Type & Description \\
\hline 1 & N/A & BIO-D Plast \\
\hline 2 & HDPE+TDPA & $100 \%$ degradable \\
\hline 3 & N/A & $100 \%$ degradable \\
\hline 4 & Starch & Compostable 7P0147 \\
\hline 5 & Starch and Polycaprolactone & OK Compost AIB VINCOTTE \\
\hline 6 & N/A & Compostable 7P0202 \\
\hline 7 & Natural material & Compostable 7P0073 \\
\hline 8 & Cellulose (reference mixture) & - \\
\hline
\end{tabular}

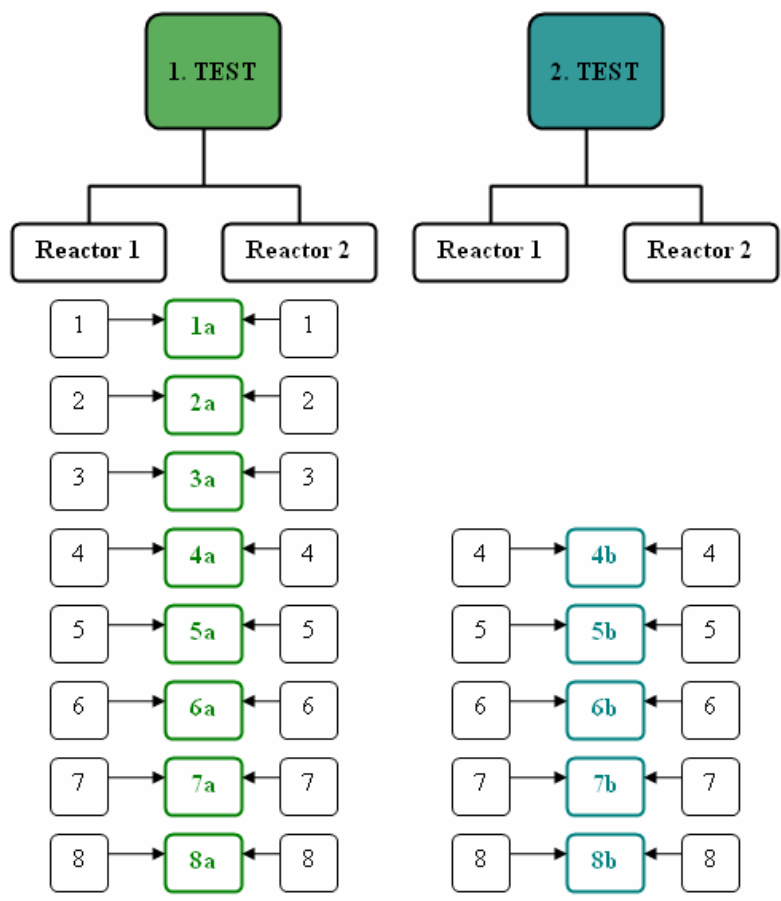

Fig. 1. Block diagram of the experiment setup

\section{Composting and the degree of biodisintegration}

Composting and the degree of biodisintegration was assessed using modified version of ČSN EN 14806 Norm "Packaging - Preliminary evaluation of the disintegration of the packaging materials under simulated composting conditions in a laboratory scale test" [18] and a modified version of ČSN EN ISO 20200 "Plastics - Determination of the degree of 
disintegration of plastic materials under simulated composting conditions in a laboratory-scale test" (ISO 20200:2004) [19]. The composting setup used was described in Ecological Chemistry and Engineering S [15].

For each tested material two reactors were prepared following the ČSN EN 14806 Norm. It is a modification compared to the ČSN EN ISO 20200 Norm which requires minimum of three reactors for each tested sample. The ČSN EN 14806 Norm states as useful for the control of the development in the reactor in which the composting takes place to undertake a blind experiment without the tested material. The authors modified the procedure stated in the Norm and in order to safeguard the presence of suitable conditions for biodegradation filter paper was used. The control of humidity was carried out under the ČSN EN 14806 Norm, not according to the ČSN EN ISO 20200 [19].

According to these tests, the plastic pieces obtained were mixed with a solid biodegradable synthetic material and subjected to aerobic degradation. However, the composition of the synthetic material was changed as follows (as percentage of dry mass): $51 \%$ compost, $4 \%$ wood sawdust, $44 \%$ biodegradable municipal waste, and $1 \%$ glucose. This modification was undertaken in order to bring the test nearer to real conditions and is based on research on the monthly production of biodegradable waste in twenty families.

The test items were added as pieces to a mixture of wet synthetic material and aerobically composted in an air circulation oven at a constant temperature of $58.0^{\circ} \mathrm{C}\left( \pm 2^{\circ} \mathrm{C}\right)$ for 12 weeks. During the test, the contents of the vessel were regularly manually mixed and aerated. When mixing and aerating, the visual appearance of the test items was carefully checked [15].

\section{The effect of degradable/biodegradable carrier bags on the quality of compost}

Apart from disintegration/biodegradation, the laboratory experiment explored also the effect of biodegradation/degradation of biologically decomposable carrier bags on compost quality. The compost quality was assessed in the accredited laboratory C̆IA no. 1147 (LABTECH s.r.o.) in Brno. The assessment entailed analyses of selected physical and chemical characteristics of composts pursuant to the standard ČSN 465735 Industrial composts.

In addition to the exploration of the above parameters, a test was made of moisture content measurement during the composting. Moisture content was measured by screening tests during both experiments and at their end. The composted material was crimpled by hand with using as much strength as possible. At the optimum moisture content, no water will emerge between the fingers and the material will hold together after the palm has been opened [16].

\section{Results and discussion}

All the results are presented as mean values of the two reactors for the relevant sample (see Figure 1). The operational parameters showed that the test was valid. The results of the degradation/biodegradation experiment were described in detail in Ecological Chemistry and Engineering S [15]. 


\section{Chemical analysis of the substrate after the biodegradation process}

After finishing the biodegradation process, a repeated experiment was performed in order to verify the obtained data, and a chemical analysis of the substrate was carried out. The aim of the chemical analysis was to find out the influence of the qualitative parameters of the substrate after the biodegradation process of the samples. Within the chemical analysis, the content of the hazardous elements $(\mathrm{Cd}, \mathrm{Ni}, \mathrm{Pb}, \mathrm{As}, \mathrm{Cr}, \mathrm{Mo}$, and $\mathrm{Hg}$ ) and the content of nutrients $(\mathrm{Ca}, \mathrm{P}$, and $\mathrm{K})$ was analyzed.

\section{Maximum permissible amounts of substances pursuant to the standard ČSN 465735 Industrial composts}

The standard ČSN 465735 stipulates that industrial compost be brown, greyish-brown to black homogeneous material of crumbly to clotted structure without inseparable particles. It must not emanate odors indicating the presence of undesirable substances. The standard defines technical requirements, too. Industrial compost must comply with quality characteristics and not even the amount of one of the monitored elements may exceed values specified in Table 2 [17].

Table 2

Maximum permissible amounts of monitored elements in compost

\begin{tabular}{|c|c|c|c|}
\hline \multirow{2}{*}{$\begin{array}{c}\text { Monitored } \\
\text { element }\end{array}$} & \multirow{2}{*}{ Unit } & \multicolumn{2}{|c|}{$\begin{array}{c}\text { Maximum permissible amount } \\
\text { of the element in the dried out sample (by classes) }\end{array}$} \\
\cline { 3 - 4 } & & I & II \\
\hline arsenic & {$[\mathrm{mg} / \mathrm{kg} \mathrm{d.m.]}$} & 10 & 20 \\
\hline cadmium & {$[\mathrm{mg} / \mathrm{kg} \mathrm{d.m.]}$} & 2 & 4 \\
\hline chromium & {$[\mathrm{mg} / \mathrm{kg} \mathrm{d.m.]}$} & 100 & 300 \\
\hline copper & {$[\mathrm{mg} / \mathrm{kg} \mathrm{d.m.]}$} & 100 & 400 \\
\hline molybdenum & {$[\mathrm{mg} / \mathrm{kg} \mathrm{d.m.]}$} & 5 & 20 \\
\hline nickel & {$[\mathrm{mg} / \mathrm{kg} \mathrm{d.m.]}$} & 50 & 70 \\
\hline lead & {$[\mathrm{mg} / \mathrm{kg} \mathrm{d.m.]}$} & 100 & 300 \\
\hline zinc & {$[\mathrm{mg} / \mathrm{kg} \mathrm{d.m.]}$} & 300 & 600 \\
\hline mercury & {$[\mathrm{mg} / \mathrm{kg} \mathrm{d.m.]}$} & 1.0 & 1.5 \\
\hline
\end{tabular}

Class II can be used only to fertilize soils in which analyses did not reveal the content of any of monitored elements higher than specified limits for soils and at the same time, the exchangeable soil reaction must not be lower than $\mathrm{pH}$ 6.0. Class II must not be used to fertilize soils on which crops are grown for direct consumption. The maximum permissible dose of Class II compost is $20 \mathrm{Mg}$ d.m. (dry mass) per hectare. Composts of Class I and Class II can be applied to soils once in three years at maximum. If some value of monitored elements for Class II is exceeded, the concerned industrial compost must not be dispatched and must be reworked [17].

\section{The analysis of samples}

Compost samples were analyzed in the testing accredited laboratory ČIA no. 1147 (LABTECH s.r.o. Brno). Parameters analyzed in the compost samples were as follows: dry weight of the original sample, dry weight of the laboratory sample $\left(105^{\circ} \mathrm{C}\right)$, exchange soil reaction $\left(\mathrm{CaCl}_{2}\right)$, Melich III - contents of available nutrients (calcium, magnesium, 
potassium, total phosphorus) and total contents of arsenic, cadmium, chromium, copper, molybdenum, nickel, lead, zinc and mercury.

To establish undesirable substances, the sample was extracted by using aqua regia pursuant to ISO 11466. Dry weight of the laboratory sample was determined after drying out and grinding the original sample; it does not always correspond to the dry weight of the original sample. Results of the analysis of samples (1a-8a) from the first experiment are presented in Tables 3-10.

Compost sample 1a

Table 3

\begin{tabular}{|c|c|c|c|}
\hline Parameter & Unit & Sample no. 1 & Testing method identification \\
\hline d.m. orig. sample $\left(105^{\circ} \mathrm{C}\right)$ & {$[\%]$} & 95.60 & GRA 03A: ČSN 720102 \\
\hline d.m. lab. sample $\left(105^{\circ} \mathrm{C}\right)$ & [\%] & 95.60 & GRA 03A: ČSN ISO 11465 \\
\hline Exch. soil reaction $\left(\mathrm{CaCl}_{2}\right)$ & & 7.12 & ECH 01B: ČSN ISO 10390 \\
\hline \multicolumn{4}{|c|}{ Melich III - available nutrients: } \\
\hline calcium & {$[\mathrm{mg} / \mathrm{kg}]$} & 8280 & ICP 04A: ČSN EN ISO 11885 \\
\hline magnesium & {$[\mathrm{mg} / \mathrm{kg}]$} & 1120 & ICP 04A: ČSN EN ISO 11885 \\
\hline potassium & {$[\mathrm{mg} / \mathrm{kg}]$} & 10800 & ICP 04A: ČSN EN ISO 11885 \\
\hline total phosphorus & {$[\mathrm{mg} / \mathrm{kg}]$} & 1440 & ICP 04A: ČSN EN ISO 11885 \\
\hline \multicolumn{4}{|l|}{ Total content: } \\
\hline arsenic & [mg/kg d.m.] & 4.82 & ICP 03B: ČSN EN ISO 17294 \\
\hline cadmium & [mg/kg d.m.] & 0.47 & ICP 04A: ČSN EN ISO 11885 \\
\hline chromium & [mg/kg d.m.] & 24.2 & ICP 04A: ČSN EN ISO 11885 \\
\hline copper & [mg/kg d.m.] & 52.8 & ICP 04A: ČSN EN ISO 11885 \\
\hline molybdenum & [mg/kg d.m.] & 2.77 & ICP 04A: ČSN EN ISO 11885 \\
\hline nickel & [mg/kg d.m.] & 19.10 & ICP 04A: ČSN EN ISO 11885 \\
\hline lead & [mg/kg d.m.] & 26.2 & ICP 04A: ČSN EN ISO 11885 \\
\hline zinc & [mg/kg d.m.] & 257.0 & ICP 04A: ČSN EN ISO 11885 \\
\hline mercury & [mg/kg d.m.] & 0.215 & AAS 06-07: ČSN 757440 \\
\hline
\end{tabular}

Table 4

Compost sample 2a

\begin{tabular}{|c|c|c|c|}
\hline Parameter & Unit & Sample no. 2 & Testing method identification \\
\hline d.m. orig. sample $\left(105^{\circ} \mathrm{C}\right)$ & [\%] & 96.62 & GRA 03A: ČSN 720102 \\
\hline d.m. lab. sample $\left(105^{\circ} \mathrm{C}\right)$ & [\%] & 96.92 & GRA 03A: ČSN ISO 11465 \\
\hline Exch. soil reaction $\left(\mathrm{CaCl}_{2}\right)$ & & 7.59 & ECH 01B: ČSN ISO 10390 \\
\hline \multicolumn{4}{|c|}{ Melich III - available nutrients: } \\
\hline calcium & {$[\mathrm{mg} / \mathrm{kg}]$} & 9600 & ICP 04A: ČSN EN ISO 11885 \\
\hline magnesium & {$[\mathrm{mg} / \mathrm{kg}]$} & 1310 & ICP 04A: ČSN EN ISO 11885 \\
\hline potassium & {$[\mathrm{mg} / \mathrm{kg}]$} & 10800 & ICP 04A: ČSN EN ISO 11885 \\
\hline total phosphorus & {$[\mathrm{mg} / \mathrm{kg}]$} & 1410 & ICP 04A: ČSN EN ISO 11885 \\
\hline \multicolumn{4}{|l|}{ Total content: } \\
\hline arsenic & [mg/kg d.m.] & 3.17 & ICP 03B: ČSN EN ISO 17294 \\
\hline cadmium & [mg/kg d.m.] & 0.42 & ICP 04A: ČSN EN ISO 11885 \\
\hline chromium & [mg/kg d.m.] & 32.8 & ICP 04A: ČSN EN ISO 11885 \\
\hline copper & [mg/kg d.m.] & 46.1 & ICP 04A: ČSN EN ISO 11885 \\
\hline molybdenum & [mg/kg d.m.] & $<2.50$ & ICP 04A: ČSN EN ISO 11885 \\
\hline nickel & [mg/kg d.m.] & 18.4 & ICP 04A: ČSN EN ISO 11885 \\
\hline lead & [mg/kg d.m.] & 37.5 & ICP 04A: ČSN EN ISO 11885 \\
\hline zinc & [mg/kg d.m.] & 223 & ICP 04A: ČSN EN ISO 11885 \\
\hline mercury & [mg/kg d.m.] & 0.265 & AAS 06-07: ČSN 757440 \\
\hline
\end{tabular}


Results of the analysis from the first experiment for Sample 1a are shown in Table 3. Analyzed parameters of Sample 1a are in line with parameters stipulated for Class I and Class II in the standard ČSN 465735 (see Table 2).

Results of the analysis from the first experiment for Sample 2a are shown in Table 4. Analyzed parameters of Sample $2 \mathrm{a}$ are in line with parameters stipulated for Class I and Class II in the standard ČSN 465735 (see Table 2).

Compost sample $3 \mathrm{a}$

\begin{tabular}{|c|c|c|c|}
\hline Parameter & Unit & Sample no. 3 & Testing method identification \\
\hline d.m. orig. sample $\left(105^{\circ} \mathrm{C}\right)$ & {$[\%]$} & 93.82 & GRA 03A: ČSN 720102 \\
\hline d.m. lab. sample $\left(105^{\circ} \mathrm{C}\right)$ & [\%] & 93.82 & GRA 03A: ČSN ISO 11465 \\
\hline Exch. soil reaction $\left(\mathrm{CaCl}_{2}\right)$ & & 1.17 & ECH 01B: ČSN ISO 10390 \\
\hline \multicolumn{4}{|c|}{ Melich III - available nutrients: } \\
\hline calcium & {$[\mathrm{mg} / \mathrm{kg}]$} & 9030 & ICP 04A: ČSN EN ISO 11885 \\
\hline magnesium & {$[\mathrm{mg} / \mathrm{kg}]$} & 1200 & ICP 04A: ČSN EN ISO 11885 \\
\hline potassium & {$[\mathrm{mg} / \mathrm{kg}]$} & 9900 & ICP 04A: ČSN EN ISO 11885 \\
\hline total phosphorus & {$[\mathrm{mg} / \mathrm{kg}]$} & 1590 & ICP 04A: ČSN EN ISO 11885 \\
\hline \multicolumn{4}{|l|}{ Total content: } \\
\hline arsenic & [mg/kg d.m.] & 4.20 & ICP 03B: ČSN EN ISO 17294 \\
\hline cadmium & [mg/kg d.m.] & 0.52 & ICP 04A: ČSN EN ISO 11885 \\
\hline chromium & [mg/kg d.m.] & 24.2 & ICP 04A: ČSN EN ISO 11885 \\
\hline copper & [mg/kg d.m.] & 55.0 & ICP 04A: ČSN EN ISO 11885 \\
\hline molybdenum & [mg/kg d.m.] & $<2.50$ & ICP 04A: ČSN EN ISO 11885 \\
\hline nickel & [mg/kg d.m.] & 20.0 & ICP 04A: ČSN EN ISO 11885 \\
\hline lead & [mg/kg d.m.] & 29.8 & ICP 04A: ČSN EN ISO 11885 \\
\hline zinc & [mg/kg d.m.] & 278 & ICP 04A: ČSN EN ISO 11885 \\
\hline mercury & [mg/kg d.m.] & 0.258 & AAS 06-07: ČSN 757440 \\
\hline
\end{tabular}

Compost sample 4a

\begin{tabular}{|c|c|c|c|}
\hline Parameter & Unit & Sample no. 4 & Testing method identification \\
\hline d.m. orig. sample $\left(105^{\circ} \mathrm{C}\right)$ & [\%] & 97.27 & GRA 03A: ČSN 720102 \\
\hline d.m. lab. sample $\left(105^{\circ} \mathrm{C}\right)$ & [\%] & 97.27 & GRA 03A: ČSN ISO 11465 \\
\hline Exch. soil reaction $\left(\mathrm{CaCl}_{2}\right)$ & & 7.05 & ECH 01B: ČSN ISO 10390 \\
\hline \multicolumn{4}{|c|}{ Melich III - available nutrients: } \\
\hline calcium & {$[\mathrm{mg} / \mathrm{kg}]$} & 8820 & ICP 04A: ČSN EN ISO 11885 \\
\hline magnesium & {$[\mathrm{mg} / \mathrm{kg}]$} & 1120 & ICP 04A: ČSN EN ISO 11885 \\
\hline potassium & {$[\mathrm{mg} / \mathrm{kg}]$} & 8530 & ICP 04A: ČSN EN ISO 11885 \\
\hline total phosphorus & {$[\mathrm{mg} / \mathrm{kg}]$} & 1570 & ICP 04A: ČSN EN ISO 11885 \\
\hline \multicolumn{4}{|l|}{ Total content: } \\
\hline arsenic & [mg/kg d.m.] & 3.61 & ICP 03B: ČSN EN ISO 17294 \\
\hline cadmium & [mg/kg d.m.] & 0.46 & ICP 04A: ČSN EN ISO 11885 \\
\hline chromium & [mg/kg d.m.] & 21.5 & ICP 04A: ČSN EN ISO 11885 \\
\hline copper & [mg/kg d.m.] & 45.5 & ICP 04A: ČSN EN ISO 11885 \\
\hline molybdenum & [mg/kg d.m.] & $<2.50$ & ICP 04A: ČSN EN ISO 11885 \\
\hline nickel & [mg/kg d.m.] & 16.8 & ICP 04A: ČSN EN ISO 11885 \\
\hline lead & [mg/kg d.m.] & 141 & ICP 04A: ČSN EN ISO 11885 \\
\hline zinc & [mg/kg d.m.] & 286 & ICP 04A: ČSN EN ISO 11885 \\
\hline mercury & [mg/kg d.m.] & 0.21 & AAS 06-07: ČSN 757440 \\
\hline
\end{tabular}


Results of the analysis from the first experiment for Sample 3a are shown in Table 5. Analyzed parameters of Sample 3a comply with the parameters stipulated for Class I and Class II in the standard ČSN 465735 (see Table 2).

Compost sample 5a

\begin{tabular}{|c|c|c|c|}
\hline Parameter & Unit & Sample no. 5 & Testing method identification \\
\hline d.m. orig. sample $\left(105^{\circ} \mathrm{C}\right)$ & [\%] & 95.78 & GRA 03A: ČSN 720102 \\
\hline d.m. lab. sample $\left(105^{\circ} \mathrm{C}\right)$ & [\%] & 95.78 & GRA 03A: ČSN ISO 11465 \\
\hline Exch. soil reaction $\left(\mathrm{CaCl}_{2}\right)$ & & 7.14 & ECH 01B: ČSN ISO 10390 \\
\hline \multicolumn{4}{|c|}{ Melich III - available nutrients: } \\
\hline calcium & {$[\mathrm{mg} / \mathrm{kg}]$} & 9390 & ICP 04A: ČSN EN ISO 11885 \\
\hline magnesium & {$[\mathrm{mg} / \mathrm{kg}]$} & 1150 & ICP 04A: ČSN EN ISO 11885 \\
\hline potassium & {$[\mathrm{mg} / \mathrm{kg}]$} & 8320 & ICP 04A: ČSN EN ISO 11885 \\
\hline total phosphorus & {$[\mathrm{mg} / \mathrm{kg}]$} & 1620 & ICP 04A: ČSN EN ISO 11885 \\
\hline \multicolumn{4}{|l|}{ Total content: } \\
\hline arsenic & [mg/kg d.m.] & 3.55 & ICP 03B: ČSN EN ISO 17294 \\
\hline cadmium & [mg/kg d.m.] & 0.44 & ICP 04A: ČSN EN ISO 11885 \\
\hline chromium & [mg/kg d.m.] & 22.1 & ICP 04A: ČSN EN ISO 11885 \\
\hline copper & [mg/kg d.m.] & 46.5 & ICP 04A: ČSN EN ISO 11885 \\
\hline molybdenum & [mg/kg d.m.] & $<2.50$ & ICP 04A: ČSN EN ISO 11885 \\
\hline nickel & [mg/kg d.m.] & 18.0 & ICP 04A: ČSN EN ISO 11885 \\
\hline lead & [mg/kg d.m.] & 26.3 & ICP 04A: ČSN EN ISO 11885 \\
\hline zinc & [mg/kg d.m.] & 271 & ICP 04A: ČSN EN ISO 11885 \\
\hline mercury & [mg/kg d.m.] & 0.223 & AAS 06-07: ČSN 757440 \\
\hline
\end{tabular}

Compost sample 6a

\begin{tabular}{|c|c|c|c|}
\hline Parameter & Unit & Sample no. 6 & Testing method identification \\
\hline d.m. orig. sample $\left(105^{\circ} \mathrm{C}\right)$ & {$[\%]$} & 92.54 & GRA 03A: ČSN 720102 \\
\hline d.m. lab. sample $\left(105^{\circ} \mathrm{C}\right)$ & [\%] & 92.54 & GRA 03A: ČSN ISO 11465 \\
\hline Exch. soil reaction $\left(\mathrm{CaCl}_{2}\right)$ & & 7.02 & ECH 01B: ČSN ISO 10390 \\
\hline \multicolumn{4}{|c|}{ Melich III - available nutrients: } \\
\hline calcium & {$[\mathrm{mg} / \mathrm{kg}]$} & 8020 & ICP 04A: ČSN EN ISO 11885 \\
\hline magnesium & {$[\mathrm{mg} / \mathrm{kg}]$} & 1070 & ICP 04A: ČSN EN ISO 11885 \\
\hline potassium & {$[\mathrm{mg} / \mathrm{kg}]$} & 9970 & ICP 04A: ČSN EN ISO 11885 \\
\hline total phosphorus & {$[\mathrm{mg} / \mathrm{kg}]$} & 1480 & ICP 04A: ČSN EN ISO 11885 \\
\hline \multicolumn{4}{|l|}{ Total content: } \\
\hline arsenic & [mg/kg d.m.] & 4.19 & ICP 03B: ČSN EN ISO 17294 \\
\hline cadmium & [mg/kg d.m.] & 0.48 & ICP 04A: ČSN EN ISO 11885 \\
\hline chromium & [mg/kg d.m.] & 27.0 & ICP 04A: ČSN EN ISO 11885 \\
\hline copper & [mg/kg d.m.] & 51.9 & ICP 04A: ČSN EN ISO 11885 \\
\hline molybdenum & [mg/kg d.m.] & $<2.50$ & ICP 04A: ČSN EN ISO 11885 \\
\hline nickel & [mg/kg d.m.] & 19.1 & ICP 04A: ČSN EN ISO 11885 \\
\hline lead & [mg/kg d.m.] & 25.3 & ICP 04A: ČSN EN ISO 11885 \\
\hline zinc & [mg/kg d.m.] & 263 & ICP 04A: ČSN EN ISO 11885 \\
\hline mercury & [mg/kg d.m.] & 0.256 & AAS 06-07: ČSN 757440 \\
\hline
\end{tabular}

Results of the analysis from the first experiment for Sample 4 a are shown in Table 6. Analyzed parameters of Sample 4a met nearly all parameters stipulated for Class I (see Table 2) except for the parameter concerning the total content of lead. Sample 4a contained 
$141 \mathrm{mg}$ of lead per $\mathrm{kg}$ of $\mathrm{d} . \mathrm{m}$. while the standard stipulates the maximum permissible amount in $1 \mathrm{~kg}$ of dried out sample for Class I to be 100 . Sample $4 \mathrm{a}$ conforms to parameters stipulated by the standard ČSN 465735 for Class II.

Results of the analysis from the first experiment for Sample 5a are shown in Table 7. Analyzed parameters of Sample 5a conform to parameters stipulated for Class I and Class II in the standard ČSN 465735 (see Table 2).

Results of the analysis from the first experiment for Sample 6a are shown in Table 8. Analyzed parameters of Sample 6a are in line with parameters stipulated for Class I and Class II in the standard ČSN 465735 (see Table 2).

Results of the analysis from the first experiment for Sample 7a are shown in Table 9. Analyzed parameters of Sample $7 \mathrm{a}$ are in line with parameters stipulated for Class I and Class II in the standard ČSN 465735 (see Table 2).

Compost sample 7a

\begin{tabular}{|c|c|c|c|}
\hline Parameter & Unit & Sample no. 7 & Testing method identification \\
\hline d.m. orig. sample $\left(105^{\circ} \mathrm{C}\right)$ & {$[\%]$} & 92.88 & GRA 03A: ČSN 720102 \\
\hline d.m. lab. sample $\left(105^{\circ} \mathrm{C}\right)$ & {$[\%]$} & 92.88 & GRA 03A: ČSN ISO 11465 \\
\hline Exch. soil reaction $\left(\mathrm{CaCl}_{2}\right)$ & & 6.98 & ECH 01B: ČSN ISO 10390 \\
\hline \multicolumn{4}{|c|}{ Melich III - available nutrients: } \\
\hline calcium & {$[\mathrm{mg} / \mathrm{kg}]$} & 8870 & ICP 04A: ČSN EN ISO 11885 \\
\hline magnesium & {$[\mathrm{mg} / \mathrm{kg}]$} & 1160 & ICP 04A: ČSN EN ISO 11885 \\
\hline potassium & {$[\mathrm{mg} / \mathrm{kg}]$} & 10700 & ICP 04A: ČSN EN ISO 11885 \\
\hline total phosphorus & {$[\mathrm{mg} / \mathrm{kg}]$} & 1410 & ICP 04A: ČSN EN ISO 11885 \\
\hline \multicolumn{4}{|l|}{ Total content: } \\
\hline arsenic & [mg/kg d.m.] & 3.59 & ICP 03B: ČSN EN ISO 17294 \\
\hline cadmium & [mg/kg d.m.] & 0.48 & ICP 04A: ČSN EN ISO 11885 \\
\hline chromium & [mg/kg d.m.] & 25.4 & ICP 04A: ČSN EN ISO 11885 \\
\hline copper & [mg/kg d.m.] & 51.2 & ICP 04A: ČSN EN ISO 11885 \\
\hline molybdenum & [mg/kg d.m.] & $<2.50$ & ICP 04A: ČSN EN ISO 11885 \\
\hline nickel & [mg/kg d.m.] & 18.1 & ICP 04A: ČSN EN ISO 11885 \\
\hline lead & [mg/kg d.m.] & 23.5 & ICP 04A: ČSN EN ISO 11885 \\
\hline zinc & [mg/kg d.m.] & 231 & ICP 04A: ČSN EN ISO 11885 \\
\hline mercury & [mg/kg d.m.] & 0.394 & AAS 06-07: ČSN 757440 \\
\hline
\end{tabular}

Compost sample 8a

\begin{tabular}{|c|c|c|c|}
\hline Parameter & Unit & Sample no. 8 & Testing method identification \\
\hline d.m. orig. sample $\left(105^{\circ} \mathrm{C}\right)$ & [\%] & 95.39 & GRA 03A: ČSN 720102 \\
\hline d.m. lab. sample $\left(105^{\circ} \mathrm{C}\right)$ & {$[\%]$} & 95.39 & GRA 03A: ČSN ISO 11465 \\
\hline Exch. soil reaction $\left(\mathrm{CaCl}_{2}\right)$ & & 7.15 & ECH 01B: ČSN ISO 10390 \\
\hline \multicolumn{4}{|c|}{ Melich III - available nutrients: } \\
\hline calcium & {$[\mathrm{mg} / \mathrm{kg}]$} & 8770 & ICP 04A: ČSN EN ISO 11885 \\
\hline magnesium & {$[\mathrm{mg} / \mathrm{kg}]$} & 1100 & ICP 04A: ČSN EN ISO 11885 \\
\hline potassium & {$[\mathrm{mg} / \mathrm{kg}]$} & 9380 & ICP 04A: ČSN EN ISO 11885 \\
\hline total phosphorus & {$[\mathrm{mg} / \mathrm{kg}]$} & 1520 & ICP 04A: ČSN EN ISO 11885 \\
\hline
\end{tabular}




\begin{tabular}{|c|c|c|c|}
\hline Total content: & & & \\
\hline arsenic & [mg/kg d.m.] & 3.42 & ICP 03B: ČSN EN ISO 17294 \\
\hline cadmium & [mg/kg d.m.] & 0.41 & ICP 04A: ČSN EN ISO 11885 \\
\hline chromium & [mg/kg d.m.] & 22.6 & ICP 04A: ČSN EN ISO 11885 \\
\hline copper & [mg/kg d.m.] & 48.2 & ICP 04A: ČSN EN ISO 11885 \\
\hline molybdenum & [mg/kg d.m.] & $<2.50$ & ICP 04A: ČSN EN ISO 11885 \\
\hline nickel & [mg/kg d.m.] & 16.2 & ICP 04A: ČSN EN ISO 11885 \\
\hline lead & [mg/kg d.m.] & 21.8 & ICP 04A: ČSN EN ISO 11885 \\
\hline zinc & [mg/kg d.m.] & 225 & ICP 04A: ČSN EN ISO 11885 \\
\hline mercury & [mg/kg d.m.] & 0.225 & AAS 06-07: ČSN 757440 \\
\hline
\end{tabular}

Results of the analysis from the first experiment for Sample 8a are shown in Table 10. Analyzed parameters of Sample 8a also conform to parameters stipulated for Class I and Class II in the standard ČSN 465735 (see Table 2).

A graph was plotted based on data gained from the laboratory analyses (see Fig. 2) with the values of parameters monitored in samples 1a-8a. Because all eight samples from the first experiment were in line with values stipulated in the standard for Class II, those parameters were not plotted in the Figure 2. However, one sample did not meet the values set for Class I and this is why the Figure 2 presents only parameters for the maximum permissible amounts of monitored elements in $\mathrm{mg} / \mathrm{kg}$ of dried out sample stipulated in the standard ČSN 465735 for Class I.

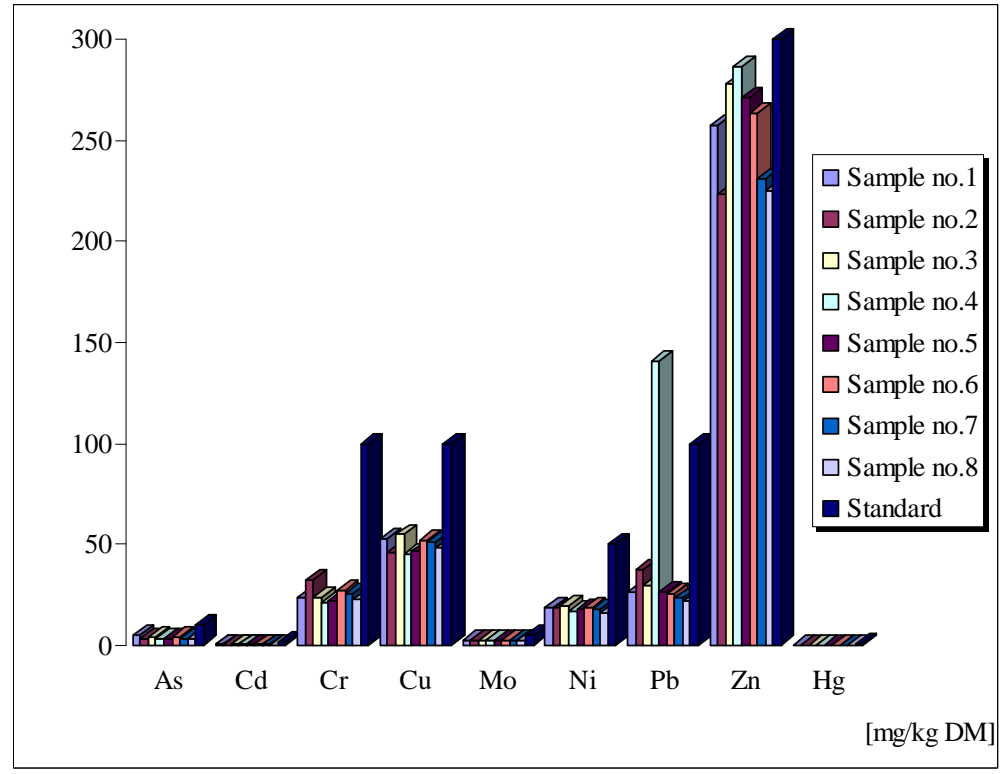

Fig. 2. Parameters of samples 1a-8a and standard values for Class I (d.m. - dry mass)

Compost samples 1a-8a meet the parameters of the maximum permissible amount of monitored substances stipulated in the standard for Class II. Results from the analysis showed increased $\mathrm{Pb}$ values in Sample $4 \mathrm{a}$ (for Class I), which was the reason for repeating 
the trial. Parameters of the remaining samples 1a, 2a, 3a, 5a, 6a, 7a and 8a were in line with the values stipulated by the standard (Table 2).

The methodology of the repeated experiment was the same as in the first trial. Harvested samples were sent for analysis to the accredited testing laboratory ČIA no. 1147 (LABTECH s.r.o. Brno).

Results from the analysis of samples in the repeated experiment are presented in Tables 11-15. The repeated analysis was made only for samples that had decomposed under laboratory conditions - including filtration paper (CFC) as positive control. Assessed parameters included only heavy metals; contents of available nutrients were not assessed.

Compost sample $4 \mathrm{~b}$

\begin{tabular}{|c|c|c|c|}
\hline Parameter & Unit & Sample no. 4 & Testing method identification \\
\hline d.m. lab. sample $\left(105^{\circ} \mathrm{C}\right)$ & {$[\%]$} & 97.34 & GRA 03A: ČSN ISO 11465 \\
\hline arsenic & {$[\mathrm{mg} / \mathrm{kg} \mathrm{d.m.]}$} & 4.40 & ICP 03B: ČSN EN ISO 17294 \\
\hline cadmium & {$[\mathrm{mg} / \mathrm{kg} \mathrm{d.m.]}$} & 0.26 & ICP 04A: ČSN EN ISO 11885 \\
\hline chromium & {$[\mathrm{mg} / \mathrm{kg} \mathrm{d.m.]}$} & 31.1 & ICP 04A: ČSN EN ISO 11885 \\
\hline copper & {$[\mathrm{mg} / \mathrm{kg} \mathrm{d.m.]}$} & 60.1 & ICP 04A: ČSN EN ISO 11885 \\
\hline molybdenum & {$[\mathrm{mg} / \mathrm{kg} \mathrm{d.m.]}$} & $<2.50$ & ICP 04A: ČSN EN ISO 11885 \\
\hline nickel & {$[\mathrm{mg} / \mathrm{kg} \mathrm{d.m.]}$} & 20.5 & ICP 04A: ČSN EN ISO 11885 \\
\hline lead & {$[\mathrm{mg} / \mathrm{kg} \mathrm{d.m.]}$} & 28.5 & ICP 04A: ČSN EN ISO 11885 \\
\hline zinc & {$[\mathrm{mg} / \mathrm{kg} \mathrm{d.m.]}$} & 265 & ICP 04A: ČSN EN ISO 11885 \\
\hline mercury & {$[\mathrm{mg} / \mathrm{kg} \mathrm{d.m.]}$} & 0.274 & AAS 06-07: ČSN 757440 \\
\hline
\end{tabular}

Compost sample $5 b$

\begin{tabular}{|c|c|c|c|}
\hline Parameter & Unit & Sample no. 5 & Testing method identification \\
\hline d.m. lab. sample $\left(105^{\circ} \mathrm{C}\right)$ & {$[\%]$} & 97.72 & GRA 03A: ČSN ISO 11465 \\
\hline arsenic & {$[\mathrm{mg} / \mathrm{kg} \mathrm{d.m.]}$} & 4.78 & ICP 03B: ČSN EN ISO 17294 \\
\hline cadmium & {$[\mathrm{mg} / \mathrm{kg} \mathrm{d.m.]}$} & 0.27 & ICP 04A: ČSN EN ISO 11885 \\
\hline chromium & {$[\mathrm{mg} / \mathrm{kg} \mathrm{d.m.]}$} & 34.1 & ICP 04A: ČSN EN ISO 11885 \\
\hline copper & {$[\mathrm{mg} / \mathrm{kg} \mathrm{d.m.]}$} & 59.5 & ICP 04A: ČSN EN ISO 11885 \\
\hline molybdenum & {$[\mathrm{mg} / \mathrm{kg} \mathrm{d.m.]}$} & $<2.50$ & ICP 04A: ČSN EN ISO 11885 \\
\hline nickel & {$[\mathrm{mg} / \mathrm{kg} \mathrm{d.m.]}$} & 19.9 & ICP 04A: ČSN EN ISO 11885 \\
\hline lead & {$[\mathrm{mg} / \mathrm{kg} \mathrm{d.m.]}$} & 29.2 & ICP 04A: ČSN EN ISO 11885 \\
\hline zinc & {$[\mathrm{mg} / \mathrm{kg} \mathrm{d.m.]}$} & 257 & ICP 04A: ČSN EN ISO 11885 \\
\hline mercury & {$[\mathrm{mg} / \mathrm{kg} \mathrm{d.m.]}$} & 0.258 & AAS 06-07: ČSN 757440 \\
\hline
\end{tabular}

Compost sample $6 \mathrm{~b}$

\begin{tabular}{|c|c|c|c|}
\hline Parameter & Unit & Sample no. 6 & Testing method identification \\
\hline d.m. lab. sample $\left(105^{\circ} \mathrm{C}\right)$ & {$[\%]$} & 97.49 & GRA 03A ČSN ISO 11465 \\
\hline arsenic & {$[\mathrm{mg} / \mathrm{kg} \mathrm{d.m.]}$} & 4.24 & ICP 03B: ČSN EN ISO 17294 \\
\hline cadmium & {$[\mathrm{mg} / \mathrm{kg} \mathrm{d.m.]}$} & 0.30 & ICP 04A: ČSN EN ISO 11885 \\
\hline chromium & {$[\mathrm{mg} / \mathrm{kg} \mathrm{d.m.]}$} & 34.6 & ICP 04A: ČSN EN ISO 11885 \\
\hline copper & {$[\mathrm{mg} / \mathrm{kg} \mathrm{d.m.]}$} & 63.5 & ICP 04A: ČSN EN ISO 11885 \\
\hline molybdenum & {$[\mathrm{mg} / \mathrm{kg} \mathrm{d.m.]}$} & $<2.50$ & ICP 04A: ČSN EN ISO 11885 \\
\hline nickel & {$[\mathrm{mg} / \mathrm{kg} \mathrm{d.m.]}$} & 21.2 & ICP 04A: ČSN EN ISO 11885 \\
\hline lead & {$[\mathrm{mg} / \mathrm{kg} \mathrm{d.m.]}$} & 31.1 & ICP 04A: ČSN EN ISO 11885 \\
\hline zinc & {$[\mathrm{mg} / \mathrm{kg} \mathrm{d.m.]}$} & 264 & ICP 04A: ČSN EN ISO 11885 \\
\hline mercury & {$[\mathrm{mg} / \mathrm{kg} \mathrm{d.m.]}$} & 0.261 & AAS 06-07: ČSN 757440 \\
\hline \multicolumn{2}{|r}{}
\end{tabular}


Compost sample $7 \mathrm{~b}$

\begin{tabular}{|c|c|c|c|}
\hline Parameter & Unit & Sample no. 7 & Testing method identification \\
\hline d.m. lab. sample $\left(105^{\circ} \mathrm{C}\right)$ & {$[\%]$} & 91.13 & GRA 03A: ČSN ISO 11465 \\
\hline arsenic & {$[\mathrm{mg} / \mathrm{kg} \mathrm{d.m.]}$} & 4.40 & ICP 03B: ČSN EN ISO 17294 \\
\hline cadmium & {$[\mathrm{mg} / \mathrm{kg} \mathrm{d.m.]}$} & $<0.25$ & ICP 04A: ČSN EN ISO 11885 \\
\hline chromium & {$[\mathrm{mg} / \mathrm{kg} \mathrm{d.m.]}$} & 33.6 & ICP 04A: ČSN EN ISO 11885 \\
\hline copper & {$[\mathrm{mg} / \mathrm{kg} \mathrm{d.m.]}$} & 62.9 & ICP 04A: ČSN EN ISO 11885 \\
\hline molybdenum & {$[\mathrm{mg} / \mathrm{kg} \mathrm{d.m.]}$} & $<2.50$ & ICP 04A: ČSN EN ISO 11885 \\
\hline nickel & {$[\mathrm{mg} / \mathrm{kg} \mathrm{d.m.]}$} & 23.2 & ICP 04A: ČSN EN ISO 11885 \\
\hline lead & {$[\mathrm{mg} / \mathrm{kg} \mathrm{d.m.]}$} & 27.1 & ICP 04A: ČSN EN ISO 11885 \\
\hline zinc & {$[\mathrm{mg} / \mathrm{kg} \mathrm{d.m.]}$} & 272 & ICP 04A: ČSN EN ISO 11885 \\
\hline mercury & {$[\mathrm{mg} / \mathrm{kg} \mathrm{d.m.]}$} & 0.279 & AAS 06-07: ČSN 757440 \\
\hline
\end{tabular}

Compost sample $8 \mathrm{~b}$

Table 15

\begin{tabular}{|c|c|c|c|}
\hline Parameter & Unit & Sample no. 8 & Testing method identification \\
\hline d.m. lab. sample $\left(105^{\circ} \mathrm{C}\right)$ & {$[\%]$} & 97.77 & GRA 03A: ČSN ISO 11465 \\
\hline arsenic & {$[\mathrm{mg} / \mathrm{kg} \mathrm{d.m.]}$} & 4.18 & ICP 03B: ČSN EN ISO 17294 \\
\hline cadmium & {$[\mathrm{mg} / \mathrm{kg} \mathrm{d.m.]}$} & $<0.25$ & ICP 04A: ČSN EN ISO 11885 \\
\hline chromium & {$[\mathrm{mg} / \mathrm{kg} \mathrm{d.m.]}$} & 34.8 & ICP 04A: ČSN EN ISO 11885 \\
\hline copper & {$[\mathrm{mg} / \mathrm{kg} \mathrm{d.m.]}$} & 60.8 & ICP 04A: ČSN EN ISO 11885 \\
\hline molybdenum & {$[\mathrm{mg} / \mathrm{kg} \mathrm{d.m.]}$} & $<2.50$ & ICP 04A: ČSN EN ISO 11885 \\
\hline nickel & {$[\mathrm{mg} / \mathrm{kg} \mathrm{d.m.]}$} & 20.8 & ICP 04A: ČSN EN ISO 11885 \\
\hline lead & {$[\mathrm{mg} / \mathrm{kg} \mathrm{d.m.]}$} & 29.0 & ICP 04A: ČSN EN ISO 11885 \\
\hline zinc & {$[\mathrm{mg} / \mathrm{kg} \mathrm{d.m.]}$} & 262 & ICP 04A: ČSN EN ISO 11885 \\
\hline mercury & {$[\mathrm{mg} / \mathrm{kg} \mathrm{d.m.]}$} & 0.261 & AAS 06-07: ČSN 757440 \\
\hline
\end{tabular}

The analysis of samples from the repeated experiment was followed by the comparison of results with those from the first experiment. The compared samples were 4, 5, 6, 7 and 8 and the obtained values were plotted in Figures 3-7.

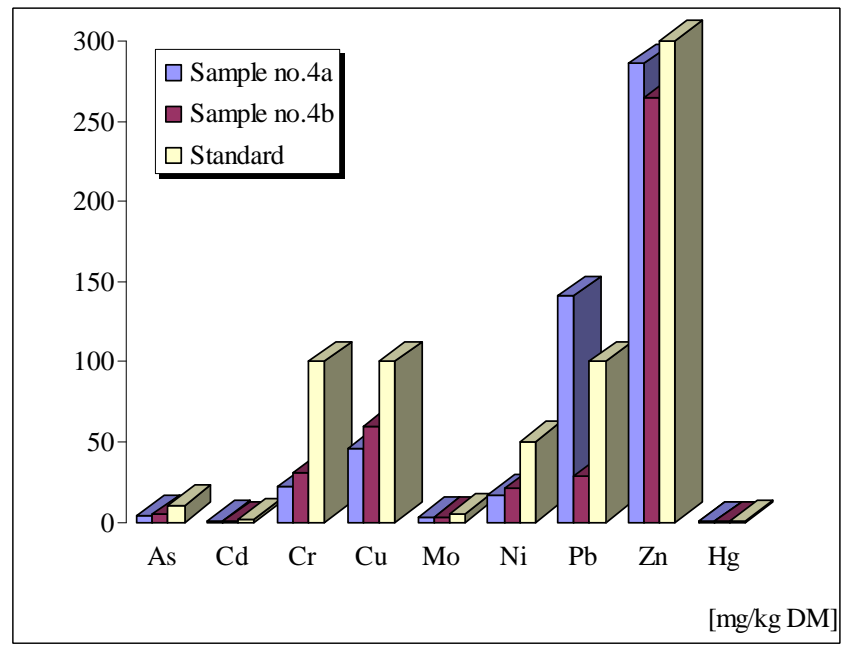

Fig. 3. Comparison of Sample 4a and Sample 4b (Mo $<2.5 \mathrm{mg} / \mathrm{kg}$ d.m. (dry mass)) 
Sample 4a exhibited an increased $\mathrm{Pb}$ value $(141 \mathrm{mg} / \mathrm{kg}$ d.m. $)$ and Sample $4 \mathrm{~b}$ from the repeated experiment showed the $\mathrm{Pb}$ value of $28.5 \mathrm{mg} / \mathrm{kg} \mathrm{d.m}$., ie the monitored element met the limits stipulated by the standard for both classes. Figure 3 presents parameters of Sample $4 \mathrm{a}$ and Sample 4b. Furthermore, the parameters of these samples are compared with values set by the standard ČSN 465735 (see Table 2). As it follows out from the Figure 3, the values of monitored parameters did not exceed values stipulated in the standard.

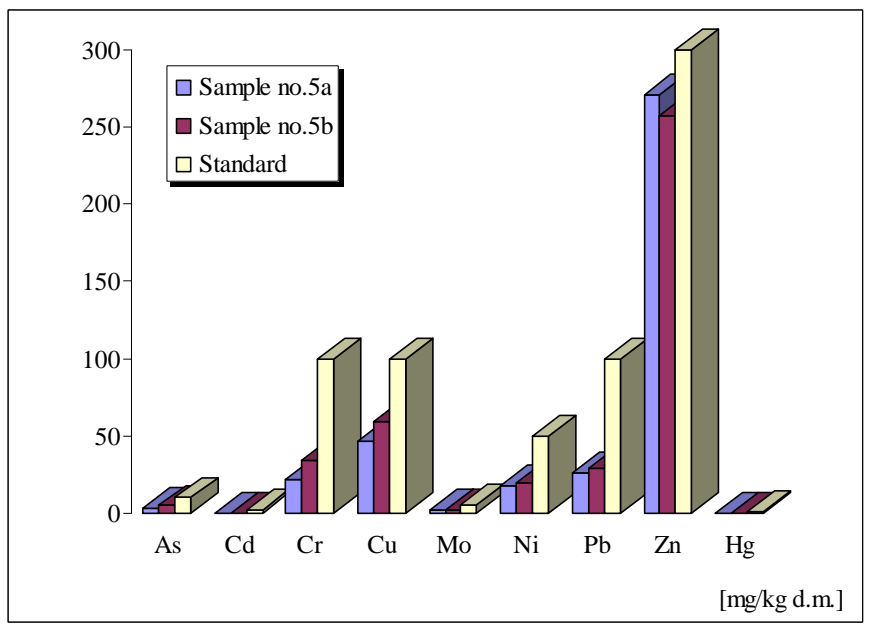

Fig. 4. Comparison of Sample 5a and Sample $5 \mathrm{~b}$ (Mo $<2.5 \mathrm{mg} / \mathrm{kg}$ d.m. (dry mass))

Figure 4 illustrates the comparison of results detected in the monitored substances in Samples 5a and 5b. The two compared samples complied with the limits for these substances set in the standard ČSN 465735 for Class I and Class II.

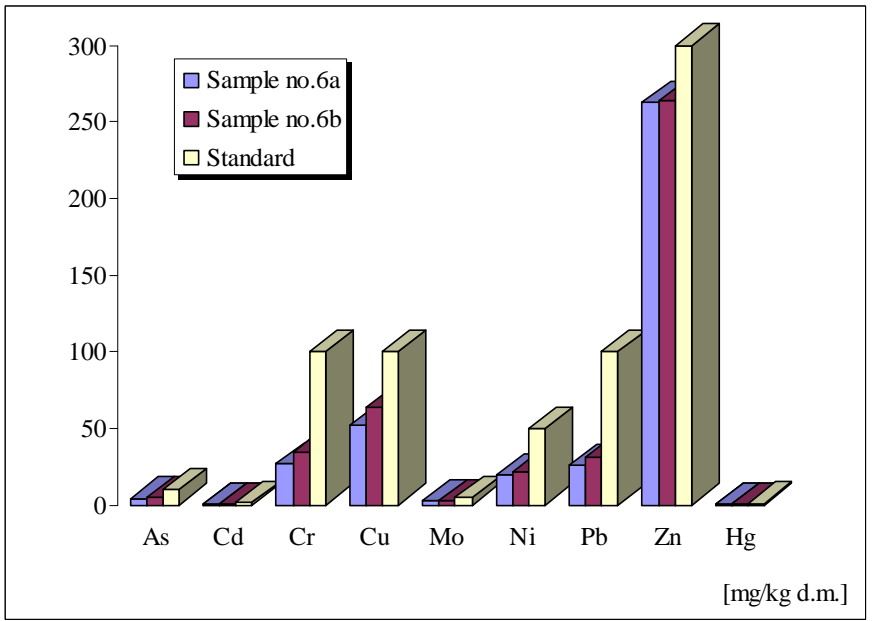

Fig. 5. Comparison of Sample 6a and Sample $6 \mathrm{~b}$ (Mo $<2.5 \mathrm{mg} / \mathrm{kg}$ d.m. (dry mass)) 
Values for Samples $6 \mathrm{a}$ and $6 \mathrm{~b}$ are shown in Figure 5, which includes - in addition to the values of the compared samples - also the limits for the monitored substances stipulated by the standard ČSN 465735 for Class I and Class II. The two compared samples did not exceed the limits for the monitored substances pursuant to the standard.

Figure 6 presents parameters of Sample 7a and Sample 7b. Parameters of these samples are compared with values set by the standard ČSN 465735 (see Table 2). As it follows out from the Figure 6, the values set by the standard were not exceeded by the monitored parameters.

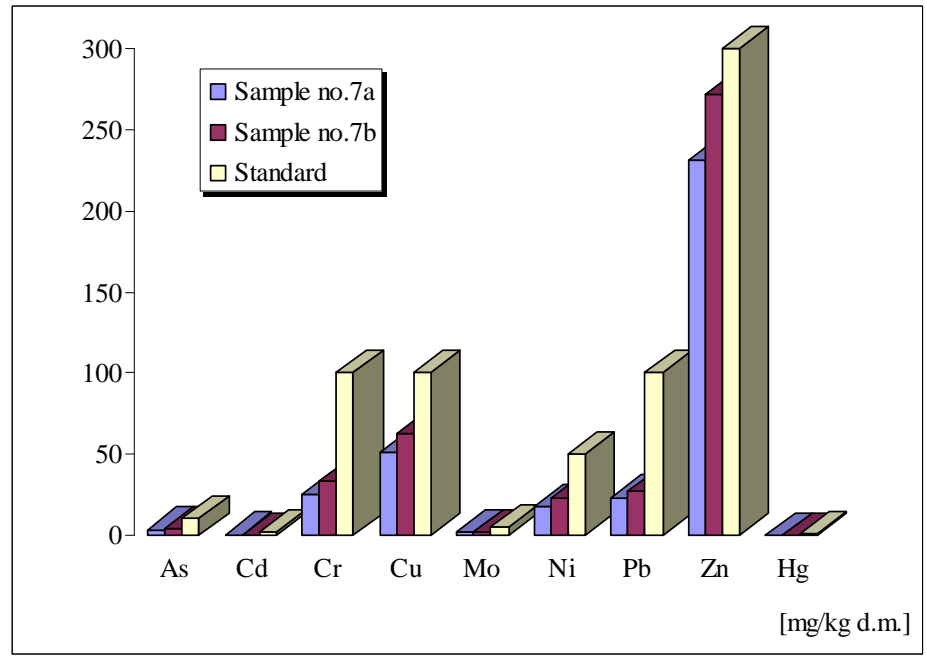

Fig. 6. Comparison of Sample 7a and Sample 7b (Mo $<2.5 \mathrm{mg} / \mathrm{kg}$ d.m. (dry mass))

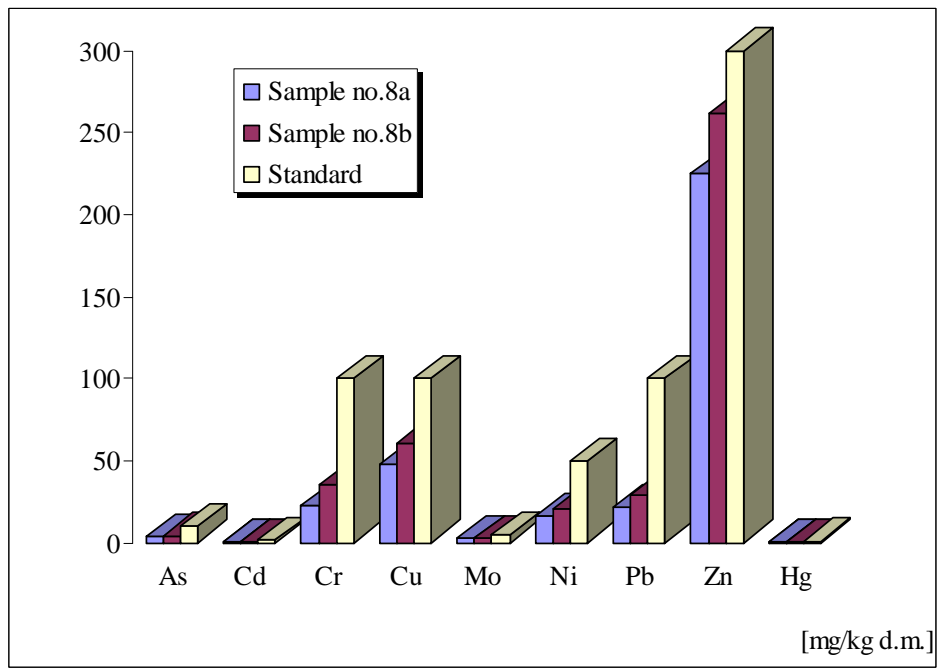

Fig. 7. Comparison of Sample 8a and Sample 8b (Mo $<2.5 \mathrm{mg} / \mathrm{kg}$ d.m. (dry mass)) 
Values for Samples 8a and 8b are shown in Figure 7, which includes - in addition to the values of the compared samples - also the limits for the monitored substances stipulated by the standard ČSN 465735 for Class I and Class II. The two compared samples did not exceed the limits for the monitored substances pursuant to the standard.

\section{Conclusions}

The goal of the experiment was to find out whether the quality of compost would change during the process of composting carrier bags claimed by manufacturers as compostable or biodegradable in terms of parameters stipulated in the standard ČSN 465735 Industrial composts. Seven samples were subjected to the composting process in laboratory conditions; positive control was filter paper (CFC) as Sample 8 (reference mixture). The compost samples were analyzed in the accredited laboratory; evaluated parameters were as follows: d.m. of the original sample, d.m. of the laboratory sample $\left(105^{\circ} \mathrm{C}\right)$, exchangeable soil reaction $\left(\mathrm{CaCl}_{2}\right)$, Melich III - contents of available nutrients (calcium, magnesium, potassium, total phosphorus), total contents of arsenic, cadmium, chromium, copper, molybdenum, nickel, lead, zinc and mercury.

All eight samples met parameters stipulated for Class II. Seven samples of the eight met parameters stipulated in the standard ČSN 465735 for Class I. Sample 4a exhibited during the analysis a higher amount of $\mathrm{Pb}$ than permissible for compost classified in Class I by the standard. This was the reason to repeat the experiment with applying the same procedure as in the first experiment. The second experiment included Sample $4 \mathrm{a}$ and samples that became decomposed under laboratory conditions including the filtration paper (CFC) as a positive control. Parameters assessed were only the contents of heavy metals; the contents of available nutrients were not evaluated.

The repeated analysis showed that the parameters conclusive for the compost quality did not exceed limits stipulated in the standard. The samples had no influence on compost characteristics: strength, content of water and salt, $\mathrm{pH}$ value, content of nutrients or proportion of organic substances; other components of the compost remained unchanged. Optical changes of the compost did not occur either.

\section{Acknowledgments}

This study was supported by the Research plan No.MSM6215648905 "Biological and technological aspects of sustainability of controlled ecosystems and their adaptability to climate change“, which is financed by the Ministry of Education, Youth and Sports of the Czech Republic.

\section{References}

[1] Ali Shah A, Hasan F, Hameed A, Ahmed S. Biological degradation of plastics: A comprehensive review. Biotechnol Advanc. 2008;26:246-265. DOI: 10.1016/j.biotechadv.2007.12.005.

[2] Tosin M, Degli-Innocenti F, Bastioli C. Detection of a toxic product released by a polyurethane-containing film using a composting test method based on a mineral bed. J Environ Polym Degrad. 1998;6:79-90. DOI: 10.1023/A:1022854105320.

[3] Gu JD, Eberiel DT, McCarthy SP, Gross RA. Cellulose acetate biodegradability upon exposure to simulated aerobic composting and anaerobic bioreactor environments. J Environ Polym Degrad. 1993;1:143-153. 
[4] Ohtaki A, Nakasaki K. Comparison of the weight-loss degradability of various biodegradable plastics under laboratory composting conditions. J Mater Cycles Waste Manage. 2000;2:118-124. DOI: 10.1007/s10163-000-0026-7.

[5] Weiland M, Daro A, David C. Biodegradation of thermally oxidized polyethylene. Polym Degrad Stab. 1995;48:275-289.

[6] Choi EJ, Park JK. Study on biodegradability of PCL/SAN blend using composting method. Polym Degrad Stab. 1996;52:321-326.

[7] Yue CL, Gross RA, McCarthy SP. Composting studies of poly(b-hydroxybutyrate-co-b-hydroxyvalyrate). Polym Degrad Stab. 1996;51:205-210.

[8] Kyrikou I, Briassoulis D. Biodegradation of agricultural plastic films: A critical review. J Polym Environ. 2007;15(2):125-150. DOI 10.1007/s10924-007-0053-8.

[9] Sarasa J, Gracia JM, Javierre C. Study of the biodisintegration of a bioplastic material waste. Bioresour Technol. 2009;100(15):3764-3768. DOI: 10.1016/j.biortech.2008.11.049.

[10] Mohee R, Unmar G. Determining biodegradability of plastic materials under controlled and natural composting environments. Waste Manage. 2007;27:1486-1493. DOI: 10.1016/j.wasman.2006.07.023.

[11] Leejarkpai T, Suwanmanee U, Rudeekit Y, Mungcharoen T. Biodegradable kinetics of plastics under controlled composting conditions. Waste Manage. 2011;31:1153-1161. DOI: 10.1016/j.wasman.2010.12.011

[12] Mohee R, Unmar G. D, Mudhoo, A, Khadoo, P. Biodegradability of biodegradable/degradable plastic materials under aerobic and anaerobic conditions. Waste Manage. 2008;28:1624-1629. DOI: 10.1016/j.wasman.2007.07.003.

[13] Kale G, Kijchavengkul T, Auras R, Rubino M, Susan E. Selke, et al. Compostability of bioplastic packaging materials: An overview. Macromol Biosci. 2007;7:255-277. DOI: 10.1002/mabi.200600168.

[14] Kale G, Auras R, Singh S, Narayan R. Biodegradability of polylactide bottles in real and simulated composting conditions. Polym Test. 2007;26:1049-1061. DOI: 10.1016/j.polymertesting.2007.07.006.

[15] Vaverková M, Toman F, Adamcová D, Kotvicová J. Study of the biodegrability of degradable/biodegradable plastic material in a controlled composting environment. Ecol Chem Eng S. 2012;19(3):347-358. DOI: 10.2478/v10216-011-0025-8.

[16] Kalina M. Composting and care for land. Prague: Grada Publishing; 2004 [In Czech].

[17] ČSN 465735 Norm "Industrial composts" [In Czech].

[18] ČSN EN 14806 Norm "Packaging - Preliminary evaluation of the disintegration of the packaging materials under simulated composting conditions in a laboratory scale test" [In Czech].

[19] ČSN EN ISO 20200 "Plastics - Determination of the degree of disintegration of plastic materials under simulated composting conditions in a laboratory-scale test" (ISO 20200:2004).

\title{
WPLYW BIODEGRADACJI/DEGRADACJI MATERIAŁÓW Z TWORZYW SZTUCZNYCH NA JAKOŚĆ KOMPOSTU
}

\begin{abstract}
Abstrakt: Celem badań było określenie wpływu procesu kompostowania ,jednorazowych” plastikowych toreb dostępnych na rynku, które są oznaczone jako biodegradowalne/degradowalne, jak również toreb certyfikowanych jako nadające się do kompostu, na jakość kompostu oraz dotrzymania wymagań określonych w normie CSN 465735 Komposty przemysłowe. Osiem próbek poddano procesowi kompostowania w warunkach laboratoryjnych. Próbki powstałego kompostu analizowano w akredytowanym laboratorium. Wszystkie próbki spełniały parametry określone w normie dla klasy II. Siedem z ośmiu próbek spełniało parametry określone w normie CSN 465735 dla klasy I. Próbki poddane recyklingowi organicznemu nie miały wpływu na właściwości kompostu: konsystencję, zawartość wody i soli, wartość pH, zawartość składników odżywczych lub stosunek substancji organicznych; składniki kompostu pozostały niezmienione. Nie zaobserwowano także zmian w wyglądzie kompostu.
\end{abstract}

Słowa kluczowe: biodegradacja, kompostowanie, degradacja, kontrolowane warunki kompostowania 